\title{
PENGARUH INSENTIF DAN MOTIVASI TERHADAP KINERJA KARYAWAN PADA PT. CALIBRAMED JAKARTA SELATAN
}

\author{
Aidil Amin Effendy ${ }^{1)}$ \\ Armina Fadhilah ${ }^{2)}$
}

1) dosen universitas pamulang, email : aidilamineffendy@gmail.com

2) mahasiswi universitas pamulang, email :cups 3oftea@yahoo.com

\section{ARTICLES}

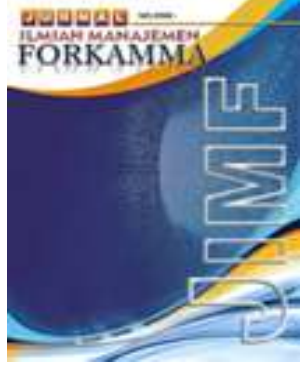

\section{JURNAL ILMIAH MANAJEMEN FORKAMMA}

\author{
Vol.1, No.3, Mei 2018 \\ Halaman : $85-96$ \\ (c) LPPM \& FORKAMMA
}

Prodi Magister Manajemen

UNVERSITAS PAMULANG

ISSN (online) : 2599-171X

ISSN (print) : :2598-9545

Keyword:

Incentives, motivation,employee performance

JEL. classification :

C33, G20, G23, N65

Contact Author :

PRODI

MAGISTER MANAJEMEN \& FORKAMMA UNPAM

JL.Surya Kencana No.1 Pamulang

Tangerang Selatan - Banten

Telp. (021) 7412566, Fax (021) 7412491 Email :

jurnalforkamma.unpam@gmail.com
Tujuan penelitian ini untuk mengetahui seberapa besar pengaruh Insentif dan Motivasi terhadap Kinerja Karyawan pada PT. Calibramed, Jakarta Selatan. Pada penelitian ini, variabel independen yaitu Insentif (X1) dan Motivasi (X2), sedangkan variabel dependen adalah Kinerja Karyawan (Y). Jenis penelitian merupakan penelitian kuantitatif dianalisis menggunakan statistik. Adapun jumlah sampel diperoleh dengan menggunakan sampel jenuh yaitu menjadikan seluruh populasi karyawan PT. Calibramed menjadi sampel yang berjumlah 52 responden. Analisis data menggunakan SPSS Versi 20. Teknik uji sampling menggunakan metode sensus dan teknik pengambilan data diantaranya uji validitas, uji reliabilitas, uji asumsi klasik meliputi uji normalitas, multikolinieritas, heterokedastisitas, serta Uji Regresi Linier Berganda, Uji Koefisien Korelasi, Uji Koefisien Determinasi, dan Uji Hipotesis. Hasil penelitian menunjukan bahwa Insentif memiliki pengaruh sebesar 19,7\% terhadap Kinerja Karyawan dan Motivasi memiliki pengaruh sebesar $47,6 \%$, adapun pengaruh secara simultan Insentif dan Motivasi terhadap Kinerja Karyawan sebesar $58,3 \%$

The purpose of this study to determine how much influence Incentives and Motivation on Employee Performance at PT. Calibramed, South Jakarta. In this study, independent variables are Incentives (X1) and Motivation (X2), while the dependent variable is Employee Performance $(Y)$. The type of research is quantitative research is analyzed using statistics. The number of samples obtained by using a saturated sample that makes the entire population of employees of PT. Calibramed into a sample of 52 respondents. Data analysis using SPSS Version 20. Sampling technique using census method and data retrieval technique such as validity test, reliability test, classical assumption test include normality test, multicolinierity, heterokedastisitas, and multiple linear regression test and hypothesis test. The results showed that incentives have an influence of $19.7 \%$ on Employee Performance and Motivation has an influence of $47.6 \%$, while the influence of simultaneous Incentives and Motivation on Employee Performance of 58.3\% 


\section{A. Pendahuluan}

Manajemen sumber daya manusia merupakan satu bidang manajemen yang khusus mempelajari hubungan dan peranan manusia dalam organisasi. Hal ini disebabkan manajemen sumber daya manusia mengatur tenaga kerja yang ada di dalam organisasi, sehingga terwujud tujuan organisasi dan kepuasan kerja karyawan. Manajemen sumber daya manusia juga dapat menghasilkan kinerja yang baik dalam sebuah perusahaan dengan cara penilaian, pemberian balas jasa dalam setiap individu anggota organisasi sesuai dengan kemampuan kerjanya. Untuk menjamin tercapainya keselaranan tujuan, pimpinan organisasi bisa memberikan perhatian dengan memberikan kompensasi, karena kompensasi merupakan bagian dari hubungan timbal balik antara organisasi dengan sumber daya manusia.

Menurut Hasibuan (2012 : 118) kompensasi adalah semua pendapatan yang berbentuk uang, barang langsung atau tidak langsung yang diterima karyawan sebagai imbalan atas jasa yang diberikan kepada perusahaan. Kompensasi dibedakan menjadi dua yaitu kompensasi langsung (direct com-pensation) berupa gaji, upah, dan upah insentif, kompensasi tidak langsung (indirect compensation atau employee welfareatau kesejahteraan karyawan).

Untuk dapat melaksanakan tugas dan fungsinya dengan sebaik mungkin maka dibutuhkan kinerja yang baik sehingga tercipta hasil kerja yang baik juga untuk perusahaan. Dengan adanya pemberian insentif yang tepat serta cara kerja yang baik. Sehingga ke depannya, proses kerja organisasi dapat berjalan sesuai dengan tujuan organisasi. Menurut Rivai (2006:384) menyatakan bahwa insentif dalah bentuk pembayaran yang dikaitkan dengan kinerja dan gainsharing, yaitu pembagian keuntungan bagi karyawan akibat peningkatan produktivitas kerja atau penghematan biaya. Sistem ini merupakan bentuk lain dari kompensasi langsung diluar gaji dan upah yang merupakan kompensasi tetap, yang disebut sistem kompensasi berdasarkan (pay for performance plan). Ahli diatas menjelaskan bahwa insentif merupakan pemberian uang di luar gaji yang dilakukan oleh pemimpin organisasi sebagai pengakuan terhadap kinerja karyawan kepada perusahaan. Apabila insentif yang diberikan perusahaan sudah tepat, maka insentif yang diberikan akan meningkatkan kinerja karyawan tersebut.

PT. Calibramed sebagai perusahaan yang menyediakan laboratorium kalibrasi turut ambil bagian dalam rangka pemenuhan harapan pemerintah di bidang kesehatan. PT. Calibramed menyediakan fasilitas laboratorium kalibrasi peralatan kesehatan yang terakreditasi oleh KAN (Komite Akreditasi Nasional) dengan ID : LK-128-IDN.PT. Calibramed didirikan dengan tujuan membantu rumah sakit mewujudkan pemenuhan kesesuaian mutu sarana, prasarana dan peralatan medik/ non medik dalam pelayanan Kesehatan di Rumah Sakit. Disamping membangun kompetensi di bidang jasa, perusahaan juga memberikan perhatian khusus kepada pembinaan SDM dalam melayani dalam jaringan customer, maupun dalam teknologi yang prima dalam pelayanan.

PT. Calibramed memberikan insentif kepada setiap karyawan secara menyeluruh namun pembagian dilihat dari jabatan yang dipegang setiap karyawan. Pembagian insentif menggunakan sistem pembagian keuntungan dimana karyawan akan mendapatkan insentif satu kali dalam setahun, dimana pembagian dilakukan jika ada keuntungan penjualan yang telah dilakukan. Pembagian insentif diberikan sesuai dengan jabatan dibagikan secara merata sejumlah karyawan yang bekerja diPT. Calibramed.

Insentif yang diberikan oleh PT. Calibramed diharapkan dapat memberikan energi positif untuk karyawan yang bekerja, dan dapat mempengaruhi perilaku serta sikap kerja karyawan sesuai dengan pencapaian target yang di tetapkan oleh PT. Calibramed besar kemungkinan mereka akan bersemangat dalam beraktivitas dan menunjukkan kinerja yang baik. Sikap positif dapat mendorong karyawan untuk selalu bekerja dengan baik dan maksimal serta menunjukkan keinginan baik mereka untuk mewujudkan tujuan perusahaan. 
Motivasi karyawan dapat kita lihat dari ketidak hadiran atau keterlambatan karyawan dalam bekerja. Hal ini dapat dijelaskan, bahwa jika karyawan tidak hadir atau terlambat dalam bekerja maka tugas yang dibebankan kepadanya akan terbengkalai atau tidak selesai sesuai yang diharapkan. Hal ini akan menimbulkan ketidak efektifan dan ketidak efisienan seseorang dalam bekerja dan lebih jauh lagi dapat menurunkan kinerja. Dalam jangka panjang hal ini dapat berdampak pada kinerja perusahaan.

Oleh karena itu salah satu cara terbaik untuk meningkatkan kinerja karyawan adalah dengan memberikan insentif kepada karyawan agar dapat memotivasi sehingga karyawan lebih meningkatkan lagi kinerjanya, ketika kinerjanya meningkat dan perusahaan pun akan mampu menghasilkan produk dengan harga yang kompetitif. Berdasarkan uraian di atas, maka penulis tertarik mengambil judul: "Pengaruh Insentif dan Motivasi Terhadap Kinerja Karyawan Pada PT. Calibramed”.

\section{B. Perumusan Masalah}

Berdasarkan latar belakang yang telah diungkapkan di atas, maka rumusan masalah dalam penelitian ini adalah :

1. Seberapa besar pengaruh Insentif terhadap Kinerja Karyawan?

2. Seberapa besar pengaruh Motivasi terhadap Kinerja Karyawan ?

3. Seberapa besar pengaruh Insentif dan Motivasi terhadap Kinerja Karyawan secara simultan?

\section{Kerangka Berpikir}

Kerangka berfikir penelitian ini dapat digambarkan sebagai berikut:

\section{PENGARUH INSENTIF DAN MOTIVASI TERHADAP KINERJA}

KARYAWAN PADAPT. CALIBRAMED - JAKARTA SELATAN

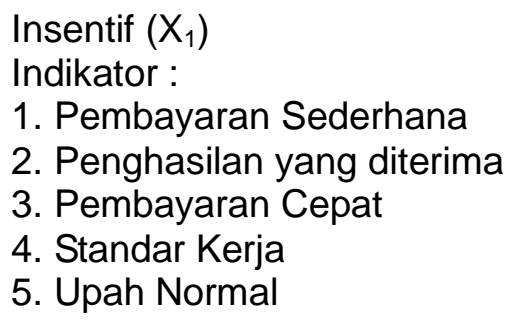

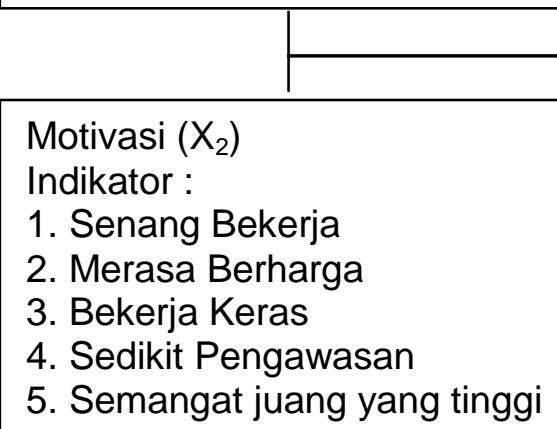

Ishak \& Hendri Tanjung (2003:27)

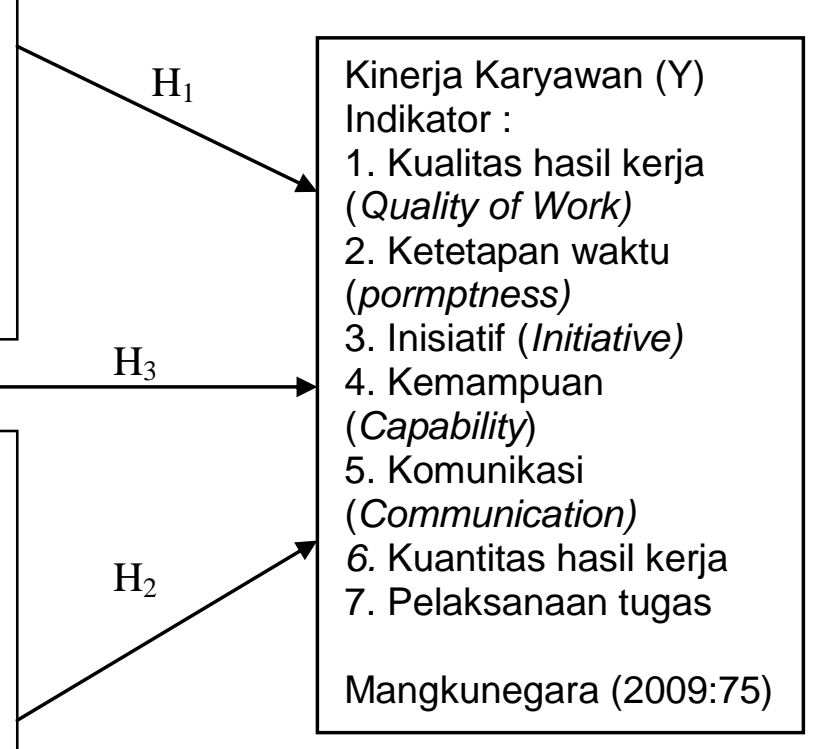

Gambar. 1.1

Kerangka Berpikir 


\section{Landasan Teori}

\section{Insentif}

Menurut Terry dalam Suwatno (2001:234), Insentif merupakan suatu yang mempengaruhi minat untuk bekerja. Ditambahkan oleh Ranupandoyo dalam Mangkunegara (2009:89), mengemukakan bahwa insentif merupakan suatu bentuk motivasi yang dinyatakan dalam bentuk uang, menurut Heru Tri (2010:154), mengemukakan bahwa insentif merupakan imbalan yang ditambahkan terhadap upah atau gaji yang biasanya berkaitan secara langsung dengan prestasi kerja. Dan menurut Hasibuan (2009:183), insentif adalah daya perangsang yang diberikan kepada karyawan tertentu berdasarkan prestasi kerjanya agar karyawan terdorong meningkatkan produktivitas kerjanya.

\section{Kualitas Pelayanan}

Motivasi didalam pribadi orang, akan berpengaruh langsung terhadap tindakan yang akan dilakukannya, karena motivasi merupakan kekuatan yang ada dalam diri seseorang untuk berbuat sesuatu yang dapat memuaskan keinginannya, hal ini sejalan dengan pandangan Sperling dalam Mangkunegara (2009:93) mengemukakan bahwa motif didefinisikan sebagai suatu kecenderungan untuk beraktifitas, dimulai dari dorongan dalam diri (drive) dan diakhiri dengan penyesuaian diri. Penyesuaian diri dikatakan untuk memuaskan motif. Encyclopedia dalam Hasibuan (2009:142) mengemukakan motivasi adalah suatu kecenderungan (suatu sifat yang merupakan pokok pertentangan) dalam diri seseorang yang dibangkitkan topangan dan mengarahkan tindak- tanduknya. Motivasi meliputi faktor kebutuhan biologis dan emosional yang hanya dapat diduga dari pengamatan tingkah laku manusia).

Stanton dalam Mangkunegara (2009:93) mendifinisikan bahwa suatu motif adalah kebutuhan yang distimulasi yang berorientasi kepada tujuan individu dalam mencapai rasa puas. Dari pengertian diatas penulis menyimpulkan bahwa motivasi adalah sesuatu yang menimbulkan semangat seseorang dalam bekerja untuk memenuhi kebutuhankebutuhannya.

\section{Kinerja Karyawan}

Setiap perusahaan didalam rekrutmen sumber daya manusia pastilah akan memilih orang- orang yang memenuhi kriteria yang sudah ditetapkan oleh perusahaan, hal ini bertujuan agar mendapatkan karyawan yang berkualitas yang dapat mengemban tugas organisasi sehingga tujuan perusahaan dapat terlaksana, untuk itu kinerja karyawan merupakan keharusan agar dapat terwujud kinerja organisasi. Prawirosentono (1999:167) mengemukakan kinerja adalah hasil kerja yang dapat dicapai oleh seseorang atau sekelompok orang dalam suatu perusahaan, sesuai dengan wewenang dan tanggung jawab masing- masing dalam rangka upaya mencapai tujuan organisasi bersangkutan secara legal, tidak melanggar hukum, dan sesuai dengan moral ataupun etika.

Cormick dan Tiffin dalam Sutrisno (2010:172) mengemukakan kinerja adalah kuantitas, kualitas, dan waktu yang digunakan dalam menjalankan tugas. Kuantitas adalah hasil yang dapat dihitung sejauh mana seseorang dapat berhasil mencapai tujuan yang telah ditetapkan. Kualitas adalah bagaimana seseorang dalam menjalankan tugasnya, yaitu mengenai banyaknya kesalahan yang dibuat, kedisiplinan dan ketepatan. Waktu kerja adalah mengenai jumlah absen yang dilakukan, keterlambatan, dan lamanya masa kerja dalam tahun yang dijalani.

Menurut para ahli diatas, penulis menyimpulkan bahwa kinerja adalah hasil kerja yang dapat dicapai oleh seseorang atau sekelompok orang dalam suatu organisasi, yang dimulai dari proses awal sampai akhir sebagai hasil yang didapat. 


\section{E. Metodologi Penelitian}

Jenis penelitian merupakan penelitian kuantitatif karena data penelitian berupa angka-angka yang nantinya akan dianalisis menggunakan statistik Penelitian ini bertujuan untuk mengetahui pengaruh Insentif, dan Motivasi Terhadap Kinerja Karyawan pada PT. Calibramed

\section{Populasi Dan Sampel}

1. Populasi

Populasi menurut Sugiyono (2006:90) adalah wilayah generalisasi yang terdiri dari obyek atau subyek yang menjadi kualitas dan karakteristik tertentu yang ditetapkan oleh peneliti untuk dipelajari dan kemudian ditarik kesimpulannya. Berdasarkan pada tempat penelitian yang telah ditetapkan, maka populasi yang dijadikan objek dalam penelitian ini adalah karyawan pada PT. Calibramed yang berjumlah 52 responden.

\section{Sampel}

Sampel menurut Sugiyono (2006:96) adalah bagian dari populasi yang dipergunakan sebagai sumber data yang sebenarnya. Dengan kata lain, sampel merupakan bagian dari populasi. Pembagian jenis sampel yang diterapkan oleh Sugiyono (2006:96) ada berbagai macam. Diantaranya penulis menerapkan dalam penelitian dengan menggunakan "Sampel Jenuh" atau "Sampling Jenuh" dimana teknik pengumpulan sampel bisa semua anggota populasi digunakan sebagai sampel. Hal ini sering dilakukan bila jumlah populasi dianggap kecil atau kurang dari 100 orang atau responden. Adapun sampel di penelitian ini yaitu 52 responden, sesuai jumlah populasi seluruh jumlah karyawan di perusahaan.

\section{Analisis Data}

Analisis data Analisis data yang digunakan dalam penelitian ini adalah uji validitas dan uji reliabilitas. Pengujian validitas menggunakan rumus korelasi pearson product moment, dengan ketentuan jika hiung $r>$ tabel $r$, berarti instrumen valid. Pengujian reliabilitas dalam penelitian ini menggunakan nilai Alpha Coanbach dengan ketentuan jika Alpha Croanbach ( hitung $r$ ) $>0,60$ berarti instrumen tersebut reliabel. Teknik analsis data antara lain uji asumsi klasik dan analisis regresi ganda. Uji asumsi klasik terdiri dari uji normalitas, uji multikolinearitas dan uji heteroskedastisitas

\section{Uji Normalitas}

Uji normalitas adalah pengujian tentang kenormalan distribusi data. Uji normalitas bisa dilakukan dengan dua cara yaitu dengan "Normal P-P Plot" dan "Tabel Kolmogorov Smirnov" yang paling umum digunakan adalah Normal P- P Plot. Pada normal P- P Plot prinsipnya normalitas dapat dideteksi dengan melihat penyebaran data (titik) pada sumbu diagonal grafik atau dengan melihat histogram dari residualnya. Jika data menyebar di sekitar garis diagonal dan mengikuti arah garis diagonal atau grafik histogramnya menunjukkan pola distribusi normal, maka model regresi memenuhi asumsi normalitas.

\section{Uji Multikolinearitas}

Uji Multikolinearitas dilakukan untuk mengetahui ada tidaknya kemiripan yang dimiliki oleh satu variabel independent dengan variabel independen yang lain dalam satu model. Pengujian multikolinearitas dalam penelitian ini menngunakan VIF (Variance Inflation Factor), dengan ketentuan jika nilai tolerance $>0,1$ dan nilai VIF $<10$, maka data tidak maka data tidak mengalami multikolinearitas. 


\section{Uji Heterokedastisitas}

Pengujian dilakukan untuk mengetahui apakah terjadi penyimpangan model karena gangguan variabel yang berbeda antar observasi ke observasi lain. Untuk mengetahui apakah terjadi heteroskedastisitas atau tidak, dapat dilihat pada gambar Scattreplot, jika pada gambar scatterplot tidak ada pola yang jelas serta titik-titik menyebar di atas dan dibawah angka 0 pada sumbu Y, maka tidak terjadi heterokedastisistas.

\section{Analisis Regresi Ganda}

Teknik analisis regresi ganda dipergunakan untuk mengetahui pengaruh Insentif dan Motivasi terhadap Kinerja Karyawan PT. Calibramed. Dengan persamaan regresi $Y=a+$ $b_{1} X_{1}+X_{2} b_{2}+X_{3} b_{3}$

Teknik pengujian hipotesis menggunakan uji parsial dan uji simultan dengan teknik probabilitas, dengan cara membandingkan nilai probabilitas Sig dengan taraf signifikansi 0,05 . Jika nilai probabilitas sig $<0,05$ maka signifikan.

\section{Koefisien Korelasi}

Pengujian koefisien korelasi ini digunakan untuk mengetahui kekuatan hubungan antara korelasi kedua variabel dimana variabel lainnya yang dianggap berpengaruh dikendalikan atau dibuat tetap (sebagai variabel kontrol). Karena variabel yang diteliti adalah interval maka teknik statistik yang diguanakan adalah Pearson Correlation Product Moment (Sugiyono, 2013:216). Analisis korelasi Pearson Product Moment dengan menggunakan rumus sebagai berikut:

$r=\frac{n \sum x y-(\Sigma x) \cdot(\Sigma y)}{\sqrt{2}\left(n \sum x^{2}-(\Sigma x)^{2} y-\left(n \Sigma y^{2}-(\Sigma y)^{2} y\right.\right.}$

Keterangan:

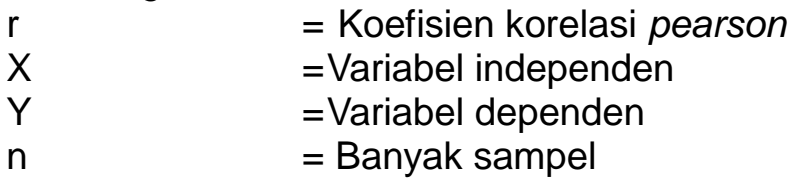

\section{Koefisien Determinasi}

Pengujian koefisien determinasi bertujuan untuk mengetahui besarnya pengaruh antar variabel. Nilai koefisien determinasi menunjukkan presentase variasi nilai variabel dependen yang dapat dijelaskan oleh persamaan regresi yang dihasilkan.

\section{Uji Hipotesis}

\section{Uji T}

Uji t digunakan untuk mengetahui hubungan masing- masing variabel independen secara individual terhadap variabel dependen. Untuk mengetahui ada tidaknya pengaruh masing- masing variable independen secara individual terhadap variabel dependen digunakan tingkat signifikasi $5 \%$ atau $(\alpha)=0,05$. Jika probability t lebih besar dari 0,05 maka tidak ada pengaruh variabel independen terhadap variable dependen (koefisien regresi tidak signifikan), sedangkan jika nilai probability t lebih kecil dari 0,05 maka terdapat pengaruh dari variable independen terhadap variable dependen.

\section{Uji $F$}

Uji statistik $\mathrm{F}$ pada dasarnya menunjukkan apakah semua variabel bebas yang dimasukkan dalam model mempunyai pengaruh secara bersama- sama terhadap variabel dependen untuk mengambil keputusan hipotesis diterima atau ditolak dengan membandingkan tingkat signifikasi sebesar 0,05.

Menurut Ghozali (2005:84) jika nilai probability $\mathrm{F}$ lebih besar dari 0,05 maka model regresi tidak dapat digunakan untuk memprediksi variabel dependen atau dengan kata lain variabel independen secara bersama- sama tidak berpengaruh terhadap variabel dependen. 


\section{F. Hasil Analisis Data dan Hasil Penelitian}

\section{Uji Validitas dan Uji Reliablitas}

Hasil uji validitas dengan menggunakn rumus korelasi product moment dan membandingkan dengan $r$ tabel dengan taraf siginfikansi sebsar $5 \%$ maka diperoleh $r$ tabel yaitu 0,273 sehingga berikut ini hasil intrumen kusiner no 1 untuk setiap variabel diperoleh nilai:

a. Insentif, instrument kuisioner no 1 diperoleh nilai $r{ }_{\text {hitung }}(0,718)>$ tabel $(0,273)$ sehingga instrument no 1 dikatakan valid.

b. Motivasi instrument kuisioner no 1 diperoleh nilai $r$ hitung $(0,331)>r_{\text {tabel }}(0,273)$ sehingga instrument no 1 dikatakan valid.

c. Kinerja Karyawan instrument kuisioner no 1 diperoleh nilai $r$ hitung $(0,288)>r_{\text {tabel }}$ $(0,273)$ sehingga instrument no 1 dikatakan valid.

Setelah dilaukan uji validitas dan seluruh intrumen di nyatakan valid, maka tahap selanjut nya adlaah uji reliabilitas dimana $r$ ca di bandingkan dengan $r$ tabel pada setiap variabel kuisioner nya:

a. Insentif, memperoleh nilai $r_{\text {ca }}(0,615)>$ tabel $(0,273)$ sehingga kusioner variabel Insentif dikatakan reliabel.

b. Motivasi, memperoleh nilai $r_{c a}(0,761)>$ tabel $(0,273)$ sehingga kusioner variabel Motivasi dikatakan reliabel

c. Kinerja Karyawan 0,610 , memperoleh nilai $r_{\text {ca }}(0,603>$ tabel $(0,273)$ sehingga kusioner variabel Insentif dikatakan reliabel

\section{Uji Asumsi Klasik}

\section{Uji Normalitas}

Uji normalitas adalah pengujian tentang kenormalan distribusi data. Pada normal PP Plot prinsipnya normalitas dapat dideteksi dengan melihat penyebaran data (titik) pada sumbu diagonal grafik atau dengan melihat histogram dari residualnya. Jika data menyebar di sekitar garis diagonal dan mengikuti arah garis diagonal atau grafik histogramnya menunjukkan pola distribusi normal, maka model regresi memenuhi asumsi normalitas.

Tabel 1.1 Uii Normalitas

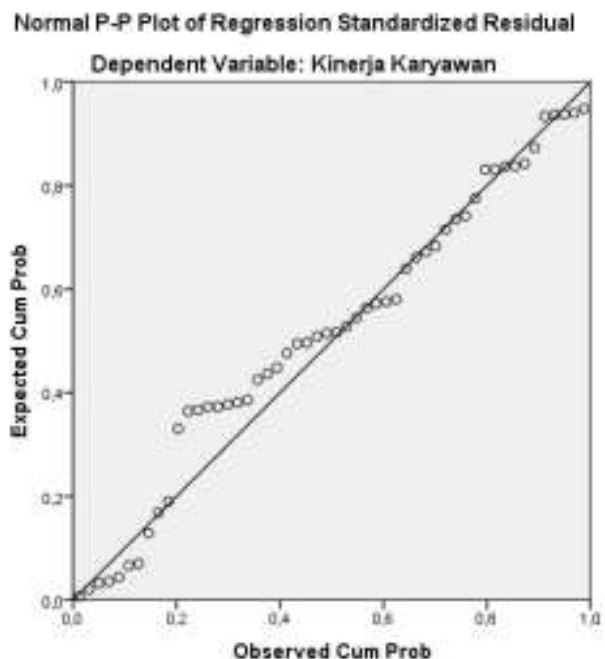

\section{Sumber: Hasil Olah Data Penelitian}

Dapat dilihat dari grafik diatas bahwa titik - titik menyebar disekitar garis dan mengikuti garis diagonal, dapat diartikan bahwa nilai residualyang dihasilkan dari regressi tersebut normal. 


\section{Uji Multikolinearitas}

Pengujian ada tidaknya gejala multikolinieritas dilakukan dengan mempertahankan nilai matriks korelasi yang dihasilkan pada saat pengolahan data serta nilai VIF (Variance Inflation Factor) dan tolerance sebagai berikut:

Tabel. 1.2 Uji Multikolinearitas

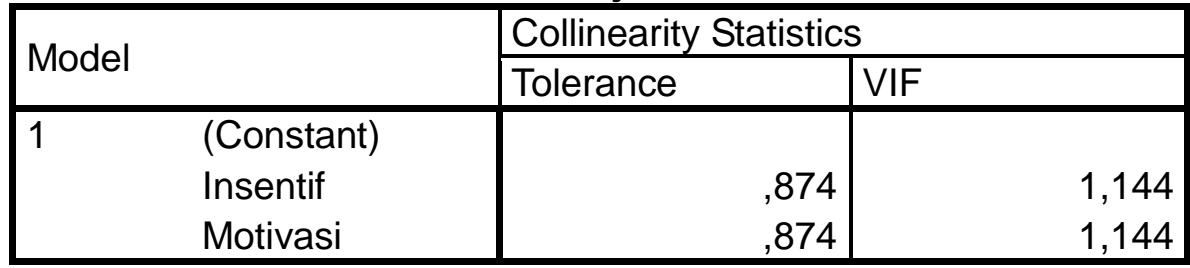

a. Dependent Variable: (Y) Kinerja Karyawan

Sumber: Hasil Olah Data Penelitian

Dari hasil output data didapatkan bahwa nilai $\mathrm{VIF}<10,00$ dan nilai tolerance $>0,10$ maka tidak terjadi gejala multikolineritas.

\section{Uji Heteroskedastisitas}

Pengujian Heteroskedastisitas ini digunakan untuk melihat apakah variabel pengganggu mempunyai varian yang sama atau tidak.

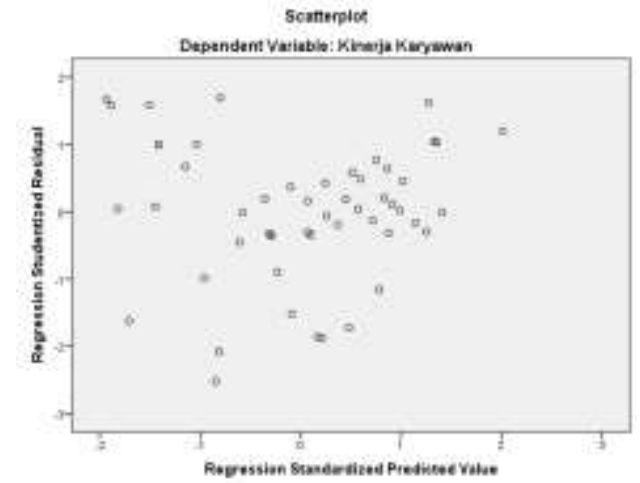

\section{Gambar. 1.1 Uji Heteroskedastisitas}

Dari output di atas dapat diketahui bahwa titik-titik tidak membentuk pola yang jelas, dan titik-titik menyebar di atas dan di bawah angka 0 pada sumbu Y. Jadi dapat disimpulkan bahwa tidak terjadi masalah heteroskedastisitas dalam model regresi.

\section{Analisis Regresi Linear Berganda}

Tabel 1.3 Analisis Regresi Linier Berganda

Coefficients $^{\mathrm{a}}$

\begin{tabular}{|c|c|c|c|c|c|}
\hline \multirow[t]{2}{*}{ Model } & \multicolumn{2}{|c|}{$\begin{array}{l}\text { Unstandardized } \\
\text { Coefficients }\end{array}$} & \multirow{2}{*}{$\begin{array}{l}\text { Standardized } \\
\text { Coefficients } \\
\text { Beta }\end{array}$} & \multirow[t]{2}{*}{$\mathrm{t}$} & \multirow[t]{2}{*}{ Sig. } \\
\hline & $B$ & Std. Error & & & \\
\hline $1 \quad$ (Constant) & 14,203 & 3,425 & & 4,147 & 000 \\
\hline Insentif & , 197 & ,082 & ,237 & 2,401 & ,020 \\
\hline Motivasi & ,476 & ,073 & ,647 & 6,556 & ,000 \\
\hline
\end{tabular}

a. Dependent Variable: Kinerja Karyawan

Sumber: Hasil Olah Data Penelitian

Model Regresi yang diperoleh $\mathrm{Y}=14.203+0.197 \mathrm{X}_{1}+\mathbf{0 . 4 7 6 \mathrm { X } _ { 2 }}$ 
1. Konstanta $(\alpha)$ sebesar 14,203 menyatakan bahwa tanpa variabel Insentif $(x 1)$ dan Motivasi (x2) maka besarnya nilai Kinerja Karyawan (y) adalah 14,203

2. Variabel Insentif $\left(x_{1}\right)$ berpengaruh postif terhadap Kinerja Karyawan (y) dengan nilai koefisiensi sebesar 0,197, yang artinya jika variabel Insentif $\left(\mathrm{x}_{1}\right)$ meningkat satu satuan dengan asumsi variabel Motivasi $\left(x_{2}\right)$ tetap, maka Kinerja Karyawan (y) akan meningkat sebesar 0,197, sehingga besar nya pengaruh Insentif $\left(x_{1}\right)$ terhadap Kinerja Karyawan $(y)$ sebesar 19,7\%.

3. Variabel Motivasi $\left(x_{2}\right)$ berpengaruh positif terhadap Kinerja Karyawan (y) dengan nilai koefisien sebesar 0,476 yang artinya jika variabel Motivasi $\left(x_{2}\right)$ meningkat satu satuan dengan asumsi variabel Insentif $\left(x_{1}\right)$ tetap, maka Kinerja Karyawan (y) akan meningkat sebesar 0,476. Sehingga besar nya pengaruh Motivasi $\left(\mathrm{x}_{2}\right)$ terhadap Kinerja Karyawan sebesar 27,6\%.

\section{Koefisien Korelasi Berganda}

Tabel 1.4 Analisis Korelasi Berganda Model Summary

\begin{tabular}{|l|l|l|l|l|}
\hline Model & $R$ & R Square & $\begin{array}{l}\text { Adjusted } \\
\text { Square }\end{array}$ & $\begin{array}{l}\text { Std. Error of } \\
\text { the Estimate }\end{array}$ \\
\hline 1 &, $764^{\mathrm{a}}$ &, 583 &, 566 & 2,16476 \\
\hline
\end{tabular}

a. Predictors: (Constant), Motivasi, Insentif

\section{Sumber: Hasil Olah Data Penelitian}

Dari Hasil Korelasi berganda antara Hubungan Insentif dan Motivasi terhadap Kinerja $\left(\mathrm{X}_{1}\right.$ dan $\mathrm{X}_{2}$ terhadap $\left.\mathrm{Y}\right)$. maka didapat korelasi antara insentif dengan kinerja karyawan $(r)$ adalah 0,764 . Hal ini menunjukkan bahwa terjadi hubungan yang kuat antara insentif dan motivasi dengan kinerja karyawan.

\section{Koefisiensi determinasi}

Mengacu pada Tabel 1.4 Analisis Korelasi Berganda Dari Hasil Koefisien Determinasi $\left(R^{2}\right)$ Insentif dan Motivasi terhadap Kinerja, diperoleh dari $R^{2} \times 100 \%$, yaitu $0,764^{2} \times 100 \%=58,3 \%$, menunjukkan bahwa prosentase sumbangan pengaruh variabel independent (insentif dan motivasi) terhadap variabel dependen (kinerja karyawan) adalah sebesar $58,3 \%$. Sedangkan sisanya sebesar $41,7 \%$ dipengaruhi oleh variabel lain yang tidak dimasukkan dalam penelitian ini.

6. Uji Hipotesis

a. Uji T

Tabel 1.5 Hasil Uji T

Coefficients $^{\mathrm{a}}$

\begin{tabular}{|c|c|c|c|c|c|}
\hline \multirow{2}{*}{ Model } & \multicolumn{2}{|c|}{$\begin{array}{l}\text { Unstandardized } \\
\text { Coefficients }\end{array}$} & \multirow{2}{*}{\begin{tabular}{|l|}
$\begin{array}{l}\text { Standardized } \\
\text { Coefficients }\end{array}$ \\
Beta
\end{tabular}} & \multirow[b]{2}{*}{$\mathrm{t}$} & \multirow[b]{2}{*}{ Sig. } \\
\hline & $B$ & $\begin{array}{l}\text { Std. } \\
\text { Error }\end{array}$ & & & \\
\hline (Constant) & 14,203 & 3,425 & & 4,147 &, 000 \\
\hline Insentif & , 197 & ,082 & ,237 & 2,401 & ,020 \\
\hline Motivasi & ,476 & ,073 & ,647 & 6,556 &, 000 \\
\hline
\end{tabular}

a. Dependent Variable: Kinerja Karyawan

\section{Sumber: Hasil Olah Data Primer}


1) Insentif $\left(X_{1}\right)$ terhadap Kinerja Karyawan $(Y)$

Berdasarkan di atas dapat dilihat bahwa variabel Insentif $\left(x_{1}\right)$ diperoleh signifikansi $\mathrm{t}$ lebih kecil dari 0,05 $(0,02<0,05)$ dan $\mathrm{t}$ hitung 2,401 $>\mathrm{t}$ tabel sebesar 2,401 $(2,401>2,009)$ atau berarti $\mathrm{H}_{01}$ ditolak dan $\mathrm{H}_{\mathrm{a} 1}$ diterima, hal ini menunjukan bahwa terdapat pengaruh yang signifikan dari Insentif $\left(x_{1}\right)$ terhadap Kinerja Karyawan (y).

2) Motivasi $\left(\mathrm{X}_{2}\right)$ terhadap Kinerja Karyawan ( $\mathrm{Y}$ )

Berdasarkan tabel diatas dapat dilihat bahwa variabel Motivasi (x2) diperoleh signifikansi $\mathrm{t}$ lebih kecil dari 0,05 $(0,000<0,05)$ dan $\mathrm{t}$ hitung 6,556 $>\mathrm{t}$ tabel sebesar 2,009 $(6,556>2,009)$ atau berarti $\mathrm{H}_{02}$ ditolak dan $\mathrm{H}_{\mathrm{a} 2}$ diterima, hal ini menunjukan bahwa terdapat pengaruh yang signifikan dari Motivasi $\left(\mathrm{x}_{2}\right)$ terhadap Kinerja Karyawan (y).

b. Uji F

Untuk menguji pengaruh Insentif $\left(x_{1}\right)$ dan Motivasi $\left(x_{2}\right)$ secara bersama-sama terhadap Kinerja Karyawan (y), dapat digunakan uji statistik $F$ (uji $F$ ), dengan menggunakan taraf signifikansi 5\% $(0,05)$.

Tabel 1.6 Hasil Uji F

ANOVA $^{a}$

\begin{tabular}{|ll|l|l|l|l|l|}
\hline \multicolumn{2}{|l|}{ Model } & $\begin{array}{l}\text { Sum of } \\
\text { Squares }\end{array}$ & df & $\begin{array}{l}\text { Mean } \\
\text { Square }\end{array}$ & F & Sig. \\
\hline $1 \quad$ Regression & 321,357 & 2 & 160,678 & 34,288 &, $000^{\mathrm{b}}$ \\
\cline { 2 - 6 } & Residual & 229,624 & 49 & 4,686 & & \\
Total & 550,981 & 51 & & & \\
\hline
\end{tabular}

a. Dependent Variable: Kinerja Karyawan

b. Predictors: (Constant), Motivasi, Insentif

\section{Sumber: Hasil Olah Data Primer}

Dari hasi uji $F$ dapat diperoelh nilai $f_{\text {hitung }}>f_{\text {tabel }}$ yaitu 34,288 $>3,18$ dan nilai sig $<0,05$ atau 0,000 0,005 "Maka, Insentif dan Motivasi memiliki pengaruh yang signifikan terhadap Kinerja Karyawan"

\section{G. Analisis Hasil Penelitian dan Pembahasan}

\section{Insentif}

a. Dari hasil uji validitas dan reliabilitas maka instrument kuisioner menunjukan valid seperti instirumen kuisioner no $1(0,718>0,273)$ dan begitupun hasil uji reliabilitas kuisioner dimana nilai $r$ ca $(0,615)>$ tabel $(0,273)$ dinyatakan reliabel.

b. Dari hasil uji analisis regresi berganda maka diperoleh nilai koefisien 0,197, sehingga besar nya pengaruh Insentif $\left(\mathrm{x}_{1}\right)$ terhadap Kinerja Karyawan $(\mathrm{y})$ sebesar $19,7 \%$.

c. Dan hasil uji hipotesis, yaitu uji t antara Insentif terhadap Kinerja Karyawan maka diperoleh nilai $\mathrm{t}_{\text {hitung }} 2,401>\mathrm{t}_{\text {tabel }}$ sebesar 2,009 $(2,401>2,009)$ atau berarti $\mathrm{H}_{01}$ ditolak dan $\mathrm{H}_{\mathrm{a} 1}$ diterima, hal ini menunjukan bahwa terdapat pengaruh yang signifikan dari Insentif $\left(x_{1}\right)$ terhadap Kinerja Karyawan (y). 


\section{Motivasi}

a. Dari hasil uji validitas dan reliabilitas maka instrument kuisioner menunjukan valid seperti instirumen kuisioner no $1(0,331>0,273)$ dan begitupun hasil uji reliabilitas kuisioner dimana nilai $r$ ca $(0,761)>$ tabel $(0,273)$ dinyatakan reliabel.

b. Dari hasil uji analisis regresi berganda maka diperoleh nilai koefisien 0,476, sehingga besarnya pengaruh Motivasi $\left(\mathrm{x}_{2}\right)$ terhadap Kinerja Karyawan $(\mathrm{y})$ sebesar $47,6 \%$.

c. Dan hasil uji hipotesis, yaitu uji $t$ antara Motivasi terhadap Kinerja Karyawan diperoleh nilai $t_{\text {hitung }} 6,556>\mathrm{t}_{\text {tabel }}$ sebesar 2,009 $(6,556>2,009)$ atau berarti $\mathrm{H}_{02}$ ditolak dan $\mathrm{H}_{\mathrm{a} 2}$ diterima, hal ini menunjukan bahwa terdapat pengaruh yang signifikan dari Motivasi $\left(\mathrm{x}_{2}\right)$ terhadap Kinerja Karyawan (y).

\section{Kinerja Karyawan}

a. Dari hasil uji validitas dan reliabilitas maka instrument kuisioner menunjukan valid seperti instirumen kuisioner no $1(0,288>0,273)$ dan begitupun hasil uji reliabilitas kuisioner dimana nilai $r$ ca $(0,603)>$ tabel $(0,273)$ dinyatakan reliabel.

b. Dari Hasil Korelasi berganda antara Hubungan Insentif dan Motivasi terhadap Kinerja $\left(\mathrm{X}_{1}\right.$ dan $\mathrm{X}_{2}$ terhadap $\left.\mathrm{Y}\right)$. maka didapat korelasi antara insentif dengan kinerja karyawan $(r)$ adalah 0,764 . Hal ini menunjukkan bahwa terjadi hubungan yang kuat antara insentif dan motivasi dengan kinerja karyawan.

c. Dari hasil koefisien determinasi dilihat dari nialai ( $R$ Square) yang diperoleh sebesar 0,583. Hal ini berarti 58,3\% Kinerja Karyawan (y) dipengaruhi oleh variabel Insentif $\left(x_{1}\right)$ dan Motivasi $\left(x_{2}\right)$ sedangkan sisanya $41,7 \%$ Kinerja Karyawan $(\mathrm{y})$ dipengaruhi oleh variabel-variabel lain yang tidak diteliti.

d. Dan hasil uji hipotesis, yaitu uji $F$ maka diperoleh nilai $f$ hitung $>f$ tabel yaitu $34,288>3,18$ dan nilai sig $<0,05$ atau 0,000 < 0,005 "Maka, Insentif dan Motivasi memiliki pengaruh yang signifikan terhadap Kinerja Karyawan"

\section{H. Kesimpulan}

1. Dari hasil analisis regresi linier berganda maka besar nya pengaruh Insentif $\left(\mathrm{x}_{1}\right)$ terhadap Kinerja Karyawan (y) sebesar 19,7\%.

2. Dari hasil analisis regresi linier bergnadan maka besar nya pengaruh Motivasi $\left(x_{2}\right)$ terhadap Kinerja Karyawan sebesar 47,6\%.

3. Dari hasil koefisien determinasi maka besar nya Insentif dan Motivasi terhadap Kinerja Karyawan sebesar 58,3 \%. 


\section{Daftar Pustaka}

Arep, Ishak dan Hendri Tanjung. 2003. "Manajemen Sumber Daya Manusia”. Jakarta: Universitas Trisakti.

Arikunto, Suharsimi. 2002, "Prosedur Penelitian”, Edisi Revisi V, Jakarta : Rineka Cipta.

Duwi Puritno.2013 "Analisis Korelasi, Regresi Dan Multivariate Dengan SPSS". Yogyakarta: Gava Media.

Ghozali , 2002. "Metode Penelitian", Jakarta : Penerbit Guna Dharma.

Hasibuan, Malayu. 2009, "Manajemen Sumberdaya Manusia”. PT. Bumi Aksara, Jakarta , 2012, Organisasi dan Motivasi, PT. Bumi Aksara, Jakarta

Mangkunegara, Anwar Prabu. 2005. "Manajemen Sumber Daya Manusia Perusahaan". Cetakan Ke Duabelas, Bandung: PT. Remaja Rosdakarya 2009. "Evaluasi Kinerja Sumber Daya Manusia”, Bandung : Rafiak

\section{Aditama}

Prawirosentono.S, 1999. "Manajemen Sumber Daya Manusia Kebijakan Kinerja Karyawan". BPFE, Yogyakarta.

Riduwan, 2009. "Metode Dan Teknik Menyusun Proposal Penelitian”, Bandung: Penerbit Alfabeta.

Sugiyono. 2003 "Metode Penelitian Kuantitatif, Kualitatif, dan R\&D”. Bandung : Alfabeta 2009 "Statistika Untuk Penelitian". Cetakan ke-25. CV. Bandung : Alfabeta, 2013, "Metode Penelitian Kombinasi", Cetakan Ke Tiga, Bandung : Alfabeta.

Sutrisno, Edy. 2009. "Manajemen Sumber Daya Manusia". Jakarta: Kencana

Suwatno. 2001. "Asas-Asas Manajemen Sumber Daya Manusia", Bandung: Suci Press

Tri, Heru, Al Fajar dan Siti. 2010. "Manajemen Sumberdaya Manusia". Yogyakarta : Sekolah Tinggi IImu Manajemen YKPN

Umar , H. 1997. "Metodologi Penelitian-Aplikasi Dalam Pemasaran”,Jakarta : Gramedia Pustaka Utama.

Veithzal, Rivai. 2006. “Manajemen Sumber Daya Manusia”. Jakarta: PT. Raja Grafindo Persada. 